feel significant and of welding them into an effective team. $\mathrm{He}$ had a healthy disrespect for unjustified bureaucracy.

He paid many visits to the mountains and was particularly keen on high level walks. His considerable knowledge and love of music was a pleasure to his friends, an asset to the University Music Society and led to a deep involvement in the management of the Bath Festival. He was largely responsible for the creation of the elegant Crafts Study Centre in Bath.

He leaves his wife Jean and two children Merlyn and Patrick.

A. H. Stride

\section{Vivi Laurent-Täckholm}

Biological science in general, and Egyptian botany in particular, has suffered a great loss with the passing of Vivi Laurent-Täckholm, who died in Stockholm on 3 May 1978, at the age of 80 .

This grand old lady had been closely associated with the University of Cairo in Giza for over 50 years, some 32 years as a professor of botany in the Herbarium. Vivi Täckholm was recognized and respected not only as the 'dean of Egyptian botany' but appreciated by all who knew her as one of those rare scientist-scholars who is completely selfless. She helped countless students and investigators both in Egypt and abroad by giving freely of her vast experience and deep erudition on all matters Egyptian, motivated only by a sincere hope that a more carefully planned research project could be launched, or if a project was near completion, that a more mature complete interpretation could be achieved.

A brief overview of her life reveals Vivi Täckholm as a very unconventional woman. She was born in Djursholm on 7 January 1898. After obtaining her fil. kand. degree in botany (embryology) in 1921 at the Stockholms Högskolas, she travelled to the U.S.A. where she worked from east coast to west coast at various jobs, including being a servant. She also began at that time her career as a writer, with a two volume work illustrated with her own photographs entitled Vivi's resa . . . (Vivi's Journey). This was first published in Stockholm (192324) and soon after in German translation (Gotha, 1925-26).

After her return to Sweden, she held a position in the editorial department of the Nordisk Familjebok (Nordic Family Book) from 1923-26 (and again in 1931-33). From 1923-25 she also worked as a journalist for various
Stockholm newspapers. She wrote the children's classic Sagan om Snipp, Snapp, Sorum (The Saga of Snipp, Snapp, Sorum) during that period (published 1926, last reprinted in 1976.)

In 1926 she married Gunnar Vilhelm Täckholm, a promising botanical investigator who had earned his doctorate at Stockholm in 1922 and had already gained a reputation for his cytological work. Gunnar Täckholm was called as Professor of Botany to the Egyptian University in Cairo (founded in 1908) in September 1925 to found a department of botany in the newly established Faculty of Science. For the next three years, Vivi aided her husband with all those duties associated with running the department (housed in the former harem building of the Za' afaran Palace) and taught the practical botany instruction for students of medicine, pharmacy and dentistry.

During those early years the need for an Egyptian flora was greatly felt, and the plans were laid for the monumental, but still unfinished Flora of Egypt. Also a number of major field trips were made and extensive botanical material collected. The Täckholms stayed in Egypt until 1929.

Vivi then spent a year and a half at the Herbier Boissier in Geneva studying and comparing their specimens with the type specimens of Flora Orientalis. She would later acknowledge the importance of this period not only for her understanding of floristics and taxonomy but for the stimulation and encouragement gained from Robert Chodat, the eminent botanist-taxonomist. Vivi Täckholm continued work on identification of Egyptian plants in Berlin, Kew, London, Weimar and Stockholm under scholarships from the Royal Swedish Academy of Sciences. She and her husband continued their collaboration until his death from tuberculosis in 1933 .

Vivi Täckholm was persuaded to continue the work her husband and she had started. The Botany Department at Cairo, especially the Herbarium, grew and profited by her association. Under difficult conditions she gradually accomplished wonders. Indeed she called herself 'the world's biggest beggar.' Largely through her labour and efforts, the herbarium grew to be one of the largest and finest in Africa; the same is true of its botanical library.

In 1941, 16 years after its inception, volume I of the Flora of Egypt authored by Vivi and Gunnar Täckholm, in collaboration with Mohammed Drar was published as a Cairo University (then Fouad I University) bulletin; volumes II, III and IV appeared in 1950, 1954 and 1966 respectively. These later volumes were co-authored by herself and her Egyp- tian collaborator and friend Drar. When Drar died in December 1964 at the age of 70, Vivi Täckholm expressed her great concern for the future of the Flora project which she continued to work on until her death.

The Flora, not unexpectedly, is an unusual work. It is a labour of love, clearly carried out unhurriedly in the tradition of those great botanical scholars she would emulate. It has been hailed as a model of scholarship and completeness. One special feature is the detailed treatment of the extensive ancient Egyptian tomb flora; another is the attention paid throughout the volumes to agriculturally important plants and economic botany. Also the enormous bibliographies, which provide access to the ancient and modern Arabic literature, are gems. Since the completion of the Flora would take many additional years, a version especially aimed at students, was published in 1956 (2nd edition 1973).

In 1952 Stockholms Högskolas conferred upon her an honorary doctorate. In April 1978 she was honored by the Roya Swedish Academy of Sciences with the gold Linné medal for her pioneering research. The Egyptian government bestowed her with high order decorations on her 60th and 70th birthdays. A special Hestschrift enticled 50 Years Cairo University Herbarlum-80 Years birthday of Vivi Täckholm was published in 1977.

In addition to several shorter, research publications, Vivi Täckholm authored numerous popular and semipopular books. In these works her supreme knowledge of Egypt as well as her deep love for plants, Egypt, and the Egyptian people is apparent. Indeed she is attributed with saying she could live without food, but not without Howers.'

Cairo University has recently decided to name the Herbarium in her honor. But the greatest legacy of Vivi Täckholm is the tradition of love for work and scholarship that she set for her many students and associates. She was also gifted with an exceptional and gentle personality. All who knew her, well or slightly, agree that they are better off, even enriched, by having associated with her. Her smile, bright eyes, fluffy snow white hair, generosity and readiness to help will be remembered warmly by many. Those who had the pleasure of visiting her at her apartment in Orman will also recall her gracious hospitality.

Her closest survivors, a brother, Professor Emeritus Torbern Laurent, her sisters Maj Laurent, textile designer and Gavonne Laurent, several nieces and nephews, and their families, are extended our deepest sympathies. Abraham D. Krikorian 